\title{
JUURNAL.RU
}

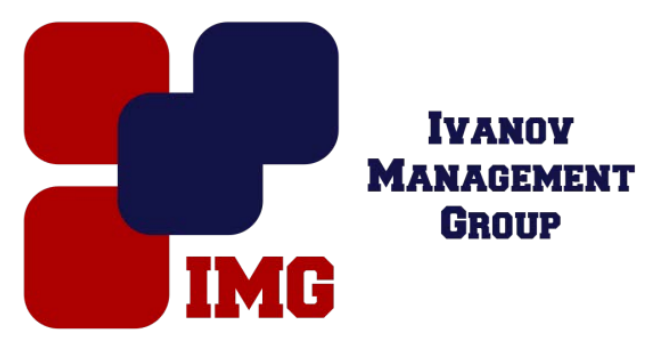

Пахомова В.В. Новосибирский Государственный Аграрный Университет Новосибирск, Россия

doi: 10.18411/lj-31-10-2016-1-10

idsp 000001:lj-31-10-2016-1-10

\section{Использование программных средств и методов сетевого управления проектами в АПК}

В настоявшее время проблема эффективного развития агробизнеса в условиях социально-экономической нестабильности в стране, неблагоприятных внешних вызовах приобретает особую актуальность. Реализация бизнеспроектов в агропромышленном комплексе требует пристального внимания, как на этапе планирования, так и на этапе реализации проекта.

Особенностью проектного управления в АПК является то, что оно подразумевает под собой не только подбор проектной команды, формирование бюджетов на реализацию, но и оптимизацию всех процессов с учетом особенностей ведения сельскохозяйственного производства [3].

Проблема в данном случае представлена противоречием между необходимостью эффективной оптимизации ресурсов при разработке и реализации проектов, наличием соответствующего инструментария и, зачастую, недостаточной проработанностью программных средств для осуществления планирования в АПК с учетом его особенностей $[5,6]$.

Созданные на базе процессора MS Excel программы для бизнес планирования в АПК не всегда позволяют должным образом оптимизировать ресурсы, обеспечить ясное видение бизнес процессов, что делает тему применения программных средств и методов в управлении проектами особенно актуальной. 
Для начала определим особенности проектного управления, так под проектом принято понимать «совокупность действий (мероприятий), направленных на достижение цели создания сложной системы с заданными характеристиками качества в ограниченные сроки и на ограниченном множестве ресурсов» [1], что подтверждает вышеназванные тезисы о необходимости оптимизации ресурсов в силу их ограниченности.

Для достижения целей проекта необходимо осуществление процессов управления, воздействия на проект как управляемую подсистему с целью его эффективной реализации. По общему определению под управлением проектами понимается «особый вид деятельности, который включает в себя планирование, контроль за выполнением работ и коррекцию плана путем применения современных методов управления» [2].

Планирование в управлении проектами является, по сути своей, основой их успешной реализации, именно на стадии планирования происходит первоначальное распределение ресурсов, определение объемов и сроков достижения промежуточных целей.

Эффективным инструментом для оптимизации ресурсов проекта выступают методы сетевого планирования и управления. Под сетевым планированием и управлением понимается «система планирования и управления разработкой проектов путём применения сетевых графиков» [2].

Технология сетевого планирования и управления предполагает использование двух основных методов: диаграммы Гантта и методов сетевого планирования (составления сетевых графиков и их оптимизация).

Диаграмма Гантта позволяет построить календарный график выполнения работ, в котором заданы сроки начала и окончания работ, образующих единый бизнес-процесс, который должен быть реализован для достижения целей проекта.

К группе сетевых методов планирования и управления как правило, относят: метод критического пути (Critical Path Method - CPM) и метод анализа и оценки программ (Prodram Evalution and Review Techique-PERT).

При применении метода критического пути формируется сетевой график, который представляет собой наглядное изображение комплекса взаимосвязанных действий, «ориентированный граф без контуров, имеющий 
одну исходную и одну завершающую вершины, в котором вершины поставлены в соответствии некоторым событиям, а дуги - работам» [1]. Одним из наиболее важных параметров сетевого графика (или иначе - сетевой модели) является продолжительность критического пути - самого продолжительного из путей от исходного события к завершающему.

Метод PERT основан на использовании в планировании трех вариантов оценок: оптимистической, пессимистической и наиболее вероятной.

Использование данных методов требует математических знаний, понимания механизмов теории игр и умения производить расчеты, что требует, как правило, много времени, соответственно, использование программных средств с одной стороны облегчает работу менеджера, а с другой стороны требует высокого уровня квалификации специалистов.

В России используются программы для сетевого и календарного планирования MO Project 2013, Spider Project, Welcom, SPU, PlanWIZARD и др.

Каждая из данных программ обладает своими достоинствами и недостатками, к плюсам, безусловно, относится возможность их использования на стандартных ПК, который не обладает характеристиками суперкомпьютеров.

Важно отметить, что при формировании проекта, выборе проектной команды необходимо организовать работу по сетевому планированию с использованием современного программного обеспечения, а представление сетевого графика и диаграммы Гантта включить в обязательную презентацию проекта, как для нужд корпораций и частного бизнеса, так и для реализации государственных и муниципальных проектов

Рост интереса к программным средствам сетевого планирования и управления обусловлен необходимостью оптимизации ресурсов при реализации проектов особенно в условиях кризиса, однако, использование данных средств требует не только навыков работы, определенных знаний, но и сформированной управленческой и предпринимательской культуры, сформированных механизмов принятия и реализации решения от идеи к реальным действиям.

Следует отметить, что использование программных средств и методов сетевого управления проектами в АПК с точки зрения государственного подхода является мощным инструментом для преодоления экономического спада [4,7]. Указанная политика должна быть реализована через внедрение инновационных 
технологий управления проектами, привлечения инвестиций, государственной поддержки хозяйственной деятельности в АПК.

\section{Литература}

1. Воробович Н.П. Математические модели, методы и алгоритмы решения задач календарного планирова-ния в управлении строительными проектами / Н.П. Воробович. - Красноярск: Изд-во КрасГАУ, - 2007.

2. Воробович Н.П., Семенов О.Ю. Программные методы и средства планирования и управления проектами // Вестник Красноярского государственного аграрного университета. - 2009. - № 10. - с. 6-11

3. Ковтун Б.А. Научно-техническое обеспечение развития АПК // Концепция стратегического развития АПК Новосибирской области до 2020 г. / Под ред. академика PACXН, д-ра экон. наук П.М. Першукевича, д-ра экон. наук И.В. Щетининой / Россельхозакадемия. Сиб. отд-ние, ГНУ СибНИИЭСХ. - Новосибирск, 2006. - С. 278-287.

4. Ковтун Б.А. Сибирская модель устойчивого развития сельских территорий /Ковтун Б.А., Папело В.Н. // АПК: Экономика, управление, 2014. - № 2.C. 71-76.

5. Муниципальное управление социально-экономическим развитием Маслянинского района Новосибирской области: Пилотный проект / В.Н. Папело, А.Н. Мельникова, Б.А. Ковтун. Под ред. В.Н. Папело. - Новосибирск: СибАГС, 2006. - 407 с.

6. Новоселов А.С. Проблемы стратегического управления экономикой региона: Монография. / Новоселов А.С., Папело В.Н., Ковтун Б.А. и др. / Под ред. Новоселова А.С. / ГОУ ВПО «СибГУТИ». - Новосибирск, 2010. $240 \mathrm{c.}$

7. Папело В.Н. Задачи стратегического управления и приоритеты развития Сибири /Ковтун Б.А., Папело В.Н.// Фундаментальные исследования, 2015. - № 12-2. - С. 392-400. 